\title{
The global significance of national inequality decline ${ }^{1}$
}

\author{
Rebecca Simson ${ }^{\text {a* }}$ and M. Savage ${ }^{\mathrm{b}}$
}

${ }^{a}$ Wadham College, University of Oxford, Oxford, United Kingdom, ${ }^{b}$ International Inequalities Institute, London School of Economics and Political Science, London, United Kingdom

*rebecca.simson@wadham.ox.ac.uk

Since the 1980s inequality has been rising in Europe, North America and parts of Asia. How does our understanding of global inequality dynamics change if coverage is extended to the rest of the developing world? To rebalance the perspective on global inequality trends, this paper surveys data and literature on recent inequality trends in Latin America, Asia, Africa and the Middle East. It finds that in these regions there are more countries with falling than rising inequality over the past 20 years, as measured by ginis of income or consumption inequality. At the global level, therefore, there are signs of inequality convergence, as inequality has been falling in countries with high inequality in the 1990s (particularly Latin America), and rising in historically low-inequality countries. We discuss the political and economic drivers of inequality decline in countries with a steady fall in the gini. This suggests some common trends across the globe, including the role of democratization, the rise of new social movements, the expansion of education and social safety nets and favourable commodity prices, in reducing income disparities. This paper calls for more country-level comparisons of inequality trends, to highlight the multiplicity of paths in this latest phase of globalization.

Keywords: inequality; global inequality; development; Africa; Asia; Latin America.

\footnotetext{
${ }^{1}$ This work was made possible by support from the Atlantic Fellows in Social and Economic Equity programme, administered by the International Inequalities Institute of the London School of Economics and Political Science. We would like to thank Paul Segal, Duncan Green, Pedro Mendes Loureiro, Beverley Skeggs, Rana Zincir-Celal and the two anonymous peer reviewers for their helpful comments.
} 


\section{Introduction}

During the middle half of the $20^{\text {th }}$ century, countries around the world underwent dramatic social transformations as incomes grew, inequality declined and living standards improved. Since roughly 1980, however, this downward trend in income inequality has reversed or stagnated in many countries. Leading researchers have warned that we are entering a troubling new era of high and persistent inequality coupled with low economic growth. ${ }^{1}$ Social scientists have shown that high levels of income inequality pose major social challenges, including declining social mobility, and declining levels of well-being, trust and social cohesion. ${ }^{2}$ The rise of racist, populist and nationalist politics in several parts of the world can also be attributed to these intensifying inequalities, as a backlash against increasingly wealthy elites drives political agendas.

Such perspectives have drawn on theoretical framings which reverse the claims of modernisation theory, which predicted a process of convergence as incomes rose, and instead hold that inequality can normally be expected to persist or increase. Thomas Piketty's now-famous argument that the rate of returns on capital is likely to continue exceeding the rate of growth $(\mathrm{r}>\mathrm{g})$, and inequality is therefore likely to continue rising, is a case in point. Such theories, however, are based on a paradigm driven by the experiences of nations in the global north, especially the United States. By extrapolating from escalating inequalities in many developed nations, this work can thus unwittingly enhance perspectives which prioritise the experiences of the $20 \%$ of the population living in OECD nations, thus marginalising the experiences of the majority of the world's population living elsewhere. As illustration, consider the experience of 'Occupy Wall St', which for a brief period in 2011 put the extreme high incomes of the ' $1 \%$ ' in the financial sector under the spotlight. Protests which began in New York spread across the developed world, driven by the fury of those who proclaimed that they were 'the 99\%' who had not enjoyed the mushrooming fortunes of bankers and financiers. Without impugning their integrity, we might nonetheless note that given that anyone earning over $\$ 51,000$ is in the global top $1 \%$, large numbers of protesters were in fact not part of the ' $99 \%$ ' if this is construed in global terms. ${ }^{3}$

Indeed, the inequality debate looks different from a global perspective. Scholars of global inequality such as Branko Milanovic, Sudhir Anand and Paul Segal have shown that global inequality trends do not straightforwardly conform to the "escalating 
inequality' model, drawing out how rising 'within nation' inequality has gone alongside falling global inequality since roughly 2000 , largely on account of rapid income growth in populous and comparatively poor counties such as China and India. ${ }^{4}$ However, there is a danger that this sets intra-national trends against global trends in too stark a way. Some nations may also be experiencing declining inequality within their own borders, as numerous studies have already shown. For instance, between roughly 2000 and 2012, most countries in Latin America saw a sizable decline in the gini index..$^{5}$ Many countries in Africa and the Middle East also appear to have experienced an inequality drop in the 1990s-2000s. ${ }^{6}$ Even in Asia, where aggregate inequality has been on the rise, there are nonetheless outliers where inequality is defying the regional trend. Relative to past periods, governments in some of these regions appear to becoming more, not less, responsive to median voter interests and are under more pressure to redistribute. Some of the more compelling theories that explain inequality dynamics fully acknowledge, indeed even predict, different inequality trajectories across countries or regions facing different economic paths or political shocks.

The aim of our paper is therefore to show how a global analysis of inequality might change if more attention is given to those regions and countries in the world where inequality is declining. Our interest is in inequality changes since 1980, the time when inequality began to rise in the western world after a half-century of falling income inequality. We will elaborate how both globalization and local forces may impact different regions or countries of the world asymmetrically, and hence bring more national variability to our analytical table. We will consider how inequality is evolving in Africa, Latin America and parts of Asia, in countries that did not undergo the warinduced levelling of inequalities that so profoundly reorganised societies in Europe, North America and parts of Asia between the 1920s and 1970s. Countries unaffected by war and other inequality-reducing crises during the $20^{\text {th }}$ century may thus also offer a glimpse of likely future dynamics in regions, such as Europe and North America, where the redistributive forces of the mid-century are wearing off.

Before we commence, we need to clarify the coverage of our paper. Firstly, this study focuses on countries in Asia, Sub-Saharan Africa, Latin America, and the Middle East and North Africa. Other than for broad comparative purposes it will not consider Eastern Europe and Central Asia. It also does not directly discuss the Caribbean, South Pacific islands or other small island states, for which inequality data is particularly 
sparse, nor high income countries in Asia such as Japan, Singapore and Korea. It focuses on within-country inequality rather than aggregate regional or global inequality, given an interest in national-level policymaking and the ability of domestic actors to influence inequality outcomes. Furthermore, it focuses on income inequality decline under conditions of rising per capita income, rather than crisis-induced inequality decline that left everyone worse off.

We find that the available, if imperfect, evidence on country-level inequality trends suggests that across the developing world, inequality has been falling in more countries than it has been rising. Improved income equity in Latin America account for many of these cases, driven by favourable external economic conditions, improved educational attainment and more progressive social policy. But several countries in north and west Africa and Asia similarly experienced falling ginis of income inequality. Rising food crop prices helped to raise the incomes of poor rural farmers in parts of Africa and Asia, as well as the rise of new social movements and popular demands for redistribution. We argue that these examples do provide evidence of various peaceful means of reducing inequality, and hold that these findings are broadly compatible with Milanovic's concepts of Kuznets waves; undulating levels of inequality driven by an interplay between economic change and political reactions to it. We conclude with a call for more research on the extent to which peaceful economic and political correctives tend, with time, to moderate extreme inequality escalations.

\section{The global inequality debate}

We situate our contribution in terms of the evolution of the inequality debate away from the United States, which provided the initial stimulus for Thomas Piketty and Emmanuel Saez's famous 2003 article which anchored attention to growing income inequality since the $1980 \mathrm{~s} .{ }^{7}$ The United States therefore became the template for the most dystopian aspects of the inequality debate, in which the pulling away of the ' $1 \%$ ' was seen as symptomatic of escalating inequalities which brought in their wake a host of related problems including declining social mobility, poor social cohesion, and the loss of health and wellbeing. ${ }^{8}$

In parallel with this bleak view of a world of rising inequality, a related literature shifted the lens from the national to the global level, thus considering between-country as well as within-country dynamics. Using national household survey data, these 
scholars analysed shifts in income inequality by pooling data from different national surveys into a composite form that allows global inequality to be analysed as if it were one country. ${ }^{9}$ This showed that inequality trends at the global level have differed substantially from national-level trends. Long-run studies found that global inequality had been rising for most of the $20^{\text {th }}$ century even as inequality fell within many countries, owing to growing between-country divergence. ${ }^{10}$ These findings dovetailed with a research strand building on world-systems theory, which explains development and income convergence in the western world as a consequence of unequal economic exchange and rising between-country inequality. ${ }^{11}$

However, more recent data efforts on global inequality have provided a less bleak picture. Milanovic argues that because of rapid economic growth in the developing world, especially the very large 'BRICs' nations (Brazil, Russia, China and India), inequality at the global level has fallen since roughly 2000. Consequently, there has been a marked shrinkage of 'citizenship rent' in recent decades as some of the world's most populous poorer nations began to converge with richer ones. ${ }^{12}$ The salience of national boundaries in differentiating between the fortunes of people in different nations has declined as poverty has been significantly reduced in poorer nations, whilst incomes at the bottom remained stagnant in richer ones. However, at the very top of the global distribution, the top 2 or $3 \%$ had done very well, along the lines that are familiar from American based research which focuses on the fortunes of the ' $1 \%$ '. This rising income share at the very top has been shown to be particularly marked when household survey data is complemented with tax data, ${ }^{13}$ which better captures top incomes, or the Forbes billionaires list for dynamics at the very peak of the distribution. ${ }^{14}$

A third and major research effort on inequality trends has gone to extending the range of national case studies to other OECD and especially European nations, to shed more light on long run within-country inequality and the drivers of change. This work has been led by Atkinson, Piketty and the team associated with the World Inequality Lab. The focus here shifted to emphasising differing inequality trajectories at the national level, to highlight similarities and differences across space. Against the American experience, some European nations (such as Denmark, France or Norway) showed milder increases in income inequality. Although this comparative perspective highlights that inequality increase is not an inexorable trend and that national policies 
make some difference, most of these countries nonetheless chartered a common path. Inequality rose during the early stages of industrialisation in the $19^{\text {th }}$ and early $20^{\text {th }}$ century, and fell in conjunction with the World Wars, the Great Depression and the postwar development of the welfare state. With growing global integration, rapid technological change and changing policy paradigms, inequality has been flat or rising since roughly $1980 .^{15}$

This growing body of evidence has in turn revitalized debates about the causes of inequality rise or decline, in particular the longstanding debates about the interplay between economic and political drivers of inequality. Simon Kuznets, who famously proposed what became known as the 'Kuznets curve' in the 1950s, saw economic forces as the main drivers of change (although he also acknowledged the role of politics), arguing that inequality took an inverted $\mathrm{U}$-shape, with a rise during the early stages of industrialisation and a fall as countries reach industrial maturity and the supply of lowskilled labour diminished. ${ }^{16}$ Another influential economic theory saw wage inequality as the outcome of 'a race between education and technology'. ${ }^{17}$ Jan Tinbergen argued that new technologies that require skilled operators of said technology will raise the returns to education and thus wage dispersion. With time this encourages more people to invest in education, thus increasing the supply of skills and decreasing the skills premium.

These ideas have been contrasted with political theory, such as those by Atkinson who emphasised the political choices countries make about redistribution. ${ }^{18}$ In contrast Piketty, and more recently Walter Scheidel, have stressed the role of political crises, be it wars, revolution or state collapse, as the main check on rising inequality, thereby highlighting that there is nothing inevitable, or automatic about inequality corrections. ${ }^{19}$ Scheidel suggests that in the absence of such crises, inequality is likely to continue rising. In his view history provides few examples of peaceful or nondestructive means of redistributing wealth and income.

In an effort to provide a synthesis, Branko Milanovic has brought together this long list of drivers into what he calls 'Kuznets waves': undulations of rising and falling inequality resulting from an interaction between economic forces (such as new technology and demographic change), and political and social pressures. ${ }^{20}$ These can take benign form (technological developments, democratisation, social pressures), or malign form (war, state collapse and revolution). In contrast to the preceding political theories, in his framework political responses to inequality are endogenous to inequality 
rise, triggered by changing economic incentives. Rising inequality eventually sows the seeds to its own destruction, either by incentivising investments in education, spawning popular pressures for greater redistribution, or precipitating conflict and crisis. To the extent that countries face similar initial economic conditions and incentives, nationallevel inequality trends will therefore tend to take similar paths.

Against these theories of inequality change, others have emphasised the stability of inequality levels, pointing to long-term historical factors that shape institutions that in turn condition inequality, such as resource endowments, slavery, colonialism and resource extraction. ${ }^{21}$ Changes in inequality observed in the last few decades have not radically altered this division between comparatively egalitarian countries in Europe and parts of Asia, relative to the historically high inequality contexts of Latin America and southern Africa.

With the possible exception of this last position, what follows from most of these theories is that we should expect to see differences in inequality cycles across countries, and differently timed peaks and troughs, where economic and political paths have differed. Given this, how far can these frameworks explain trends across the nonWestern world? Can 'atypical' examples of countries that did not have the same economic and conflict trajectories as the industrialised west help to illustrate forces at play? Do we have examples of inequality decline absent of severe political crises that point to 'benevolent' levellers? To what extent might a broader range of case studies highlight the extent to which polities can act independently of global or regional paradigms, to chart their own inequality path (a la Atkinson)? Or are the political outcomes largely a consequence of economic conditions (a la Milanovic)? The next sections will review some of the trends and findings about inequality decline across Latin America, the Middle East, Asia and Africa, before considering how these examples speak to the theory.

\section{Charting inequality trends beyond the global north}

To examine country-level inequality trends across the global south we turn to the rapidly growing databases of gini indices of income or consumption inequality, but first some discussion of the data is in order, since measurements of inequality are sensitive to both the choice of measure and source of data. Despite its critics, the most widely used inequality measure remains the gini index, a synthetic measure of income or 
consumption inequality across the entire distribution. A range of alternatives to the gini exist, which give different weight to dynamics across different parts of the income distribution. The more intuitive 'top income shares' popularized by Piketty for instance, mainly measures top income concentration, which he sees as driving inequality trends more widely.

Inequality measures are most often derived from household surveys and as a result tend to underestimate top incomes, as wealthier households are more likely to opt out of surveys or under-report their earnings. Recent work has therefore increasingly relied on tax data instead of household surveys, on the grounds that it suffers from less underreporting. ${ }^{22}$ But although collection of tax-based income share data is rapidly increasing, it is only available for a small set of developing countries and we therefore need to continue drawing from household survey-based measures if we are to do justice to the experience of many developing nations.

With growing popular and academic interest in income inequality, the coverage of inequality datasets containing data from household budget or income surveys has increased in recent years. But although the sheer amount of available data has increased, the different estimates presented in these databases are not always comparable across time and space and most datasets place onus on the user to assess the underlying data quality and usability. Of particular concern is the basis for measuring inequality, as the recorded level of inequality will differ if measured on an income or consumption basis, household or individual basis, or gross or net basis. And even where these survey differences are held constant, there are idiosyncratic variations in data collection method and questionnaire design that can bias the measure. The devil lies in these details.

We reviewed the available inequality datasets and provide a full assessment of their strengths in Online Appendix 2. This led us to concur with the guidance of Atkinson and Brandolini, and reiterated by Jenkins, that it remains safest to use sources with as little manipulation of the data as possible, and where surveys themselves rest on as similar a basis as possible. ${ }^{23} \mathrm{We}$ therefore choose to rely primarily on the SocioEconomic Database for Latin America and the Caribbean (SEDLAC) to inform the Latin American inequality analysis and the World Bank's PovcalNet for the rest of the developing world. In a few select cases we use national statistical sources as well, where these are richer than the World Bank collection. To examine average regional 
inequality, however, we turn to the more comprehensive dataset from the Global Consumption and Income Project (GCIP).

What do these data sources tell us about inequality trends across the globe? Figure 1 provides the average gini index by region (from the GCIP database). At the regional level, the data suggests that a stylized story of uninterrupted inequality growth since 1980 is far from generalizable. In many developing regions inequality rose in the 1980s or 1990s and has fallen thereafter, with a break in trend around 2000 or slightly earlier. ${ }^{24}$ As the decline was more pronounced in historically high-inequality regions, such as Latin America, Africa and the Middle East, there has been a mild convergence in within-country inequality levels. ${ }^{25}$

\section{Figure 1. Average gini by region, 1980-2014 (unweighted)}

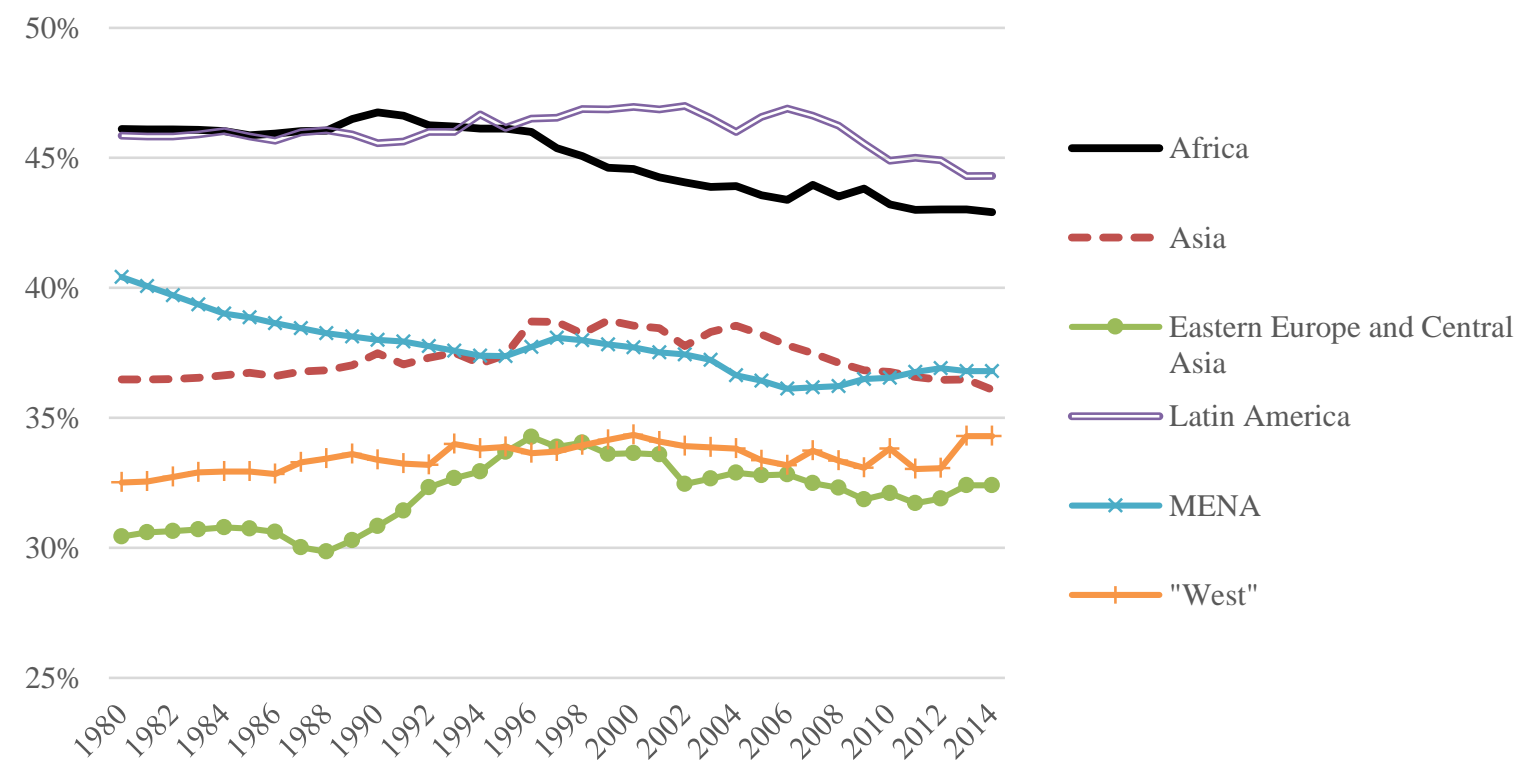

Source: Based on data from: Lahoti et al. 2016 [GCIP dataset]

The upswing in inequality in the developing world in the 1990s has been explained by the rise of inequality in Central Asia and Eastern Europe during the transition from communism, which shifted labour from a low-inequality public sector into a higher inequality private sector and privatized previously public-held assets. ${ }^{26}$ This was coupled with the economic take-off and liberalisation in some of Asia's largest economies which raised the level of income inequality in China and India in particular. Concurrently, inequality spiked in Latin America in the 1990s during the period of economic liberalization and structural reform. 
Since the 2000s in contrast, inequality growth has slowed in much of Asia and Eastern Europe and reversed in Latin America and parts of Africa. There may be a further break in the trend in 2008 following the global economic crisis. Inequality levels appear to have plateaued or fallen slightly in China and Eastern Europe since, resulting in a more rapid average rate of decline in the past decade.

The late 2000s also mark an important break in growth performance in Africa, Latin America and the Middle East. In large parts of the developing world, GDP per capita grew little, or even declined, during the 1980s and 1990s, while growth rebounded in the late 1990s or early 2000s. These regions have gone from a situation where the bottom segments of the income distribution were seeing real and relative falls in consumption per capita, to one of strong growth, disproportionately benefitting the bottom deciles relative to the upper half of the distribution. ${ }^{27}$

These regional patterns raise questions about the reasons for divergent paths across the world. What countries account for this inequality moderation? How reliable is the available data and literature and how far can it take us in identifying and explaining the drivers of country-level trends?

\section{Within-country inequality in developing countries}

Returning to the country-by-country data, we examined trends in inequality to identify those countries that showed a sizable decline in inequality in recent decades. Countries were classified into four groups (A-D) based on the gini trend and data quality. Criteria for inclusion in these four groups are set out below. The classification rests in part on a qualitative judgement of the reliability of the data. Where inequality has both risen and fallen in different decades, we gave precedence to the period of inequality decline.

(A) Strong and robust evidence of declining inequality: countries included in this group are those with a recorded gini fall of $>3$ percentage points, sustained over a period of $5+$ years (i.e. no immediate inequality reversal), and based on trustworthy and consistent data.

(B) Plausible evidence of declining inequality: data is less consistent and reliable than for Group A, but these countries also shows a sustained gini decline of $>3$ percentage points. For inclusion, the inequality decline needs to be captured by at least two successive surveys, and the pace of decline needs to be plausible (i.e., it excluding unrealistically large year to year gini swings). 
(C) Plausible evidence of increasing inequality: countries with a rise in the gini of $>3$ percentage points, sustained over at least two surveys.

(D) Inconclusive data. No clear evidence of either a fall or rise in inequality, whether due to a steady level of inequality or insufficient data.

This identified 28 developing countries that have seen a sustained decline in the gini of more than 3 percentage points in the past two decades (the full results of the analysis are presented in Online Appendix 1). Group A consists of 17 Latin American countries in addition to Thailand. In a further 10 countries we find a plausible decline in the gini measured over successive surveys (Group B). This second group comprises seven countries in north or west Africa, including Algeria, Tunisia, Burkina Faso, Guinea, Mali, Mauritania and Niger, in addition to Iran, Malaysia and Cambodia. In 48 countries there are either no signs of a change in the gini or the data is too limited or inconsistent to draw any tentative conclusions (Group D); these are primarily countries in Africa and the Middle East. In 11 countries, primarily in Asia and Africa, we see evidence of increases in income inequality (Group C). How does the existing literature explain these trends? In those countries or regions where inequality has fallen, what economic and political developments can account for these changes?

\section{Latin America}

Latin America saw a marked increase in inequality in the 1980s and 1990s followed by a fall in inequality across the region in the 2000s which has generated considerable academic interest, in part because it provides an example of a substantial inequality decline during a period of high growth, growing global economic integration and trade liberalization. ${ }^{28}$

The magnitude of the recorded decline in income inequality is sensitive to the years under review, but in aggregate there was a clear downturn starting in 2002 or shortly before, which began to taper off in 2011. As illustrated in Figure 2, 14 out of 18 Latin American countries saw a meaningful decline in the gini (of >3pts) between 2002 and 2012. Expanding the years under review suggests a decline of more than 3 pts in all countries other than Honduras and Costa Rica. 
Figure 2. Absolute change in gini pts, $2002-2012^{2}$

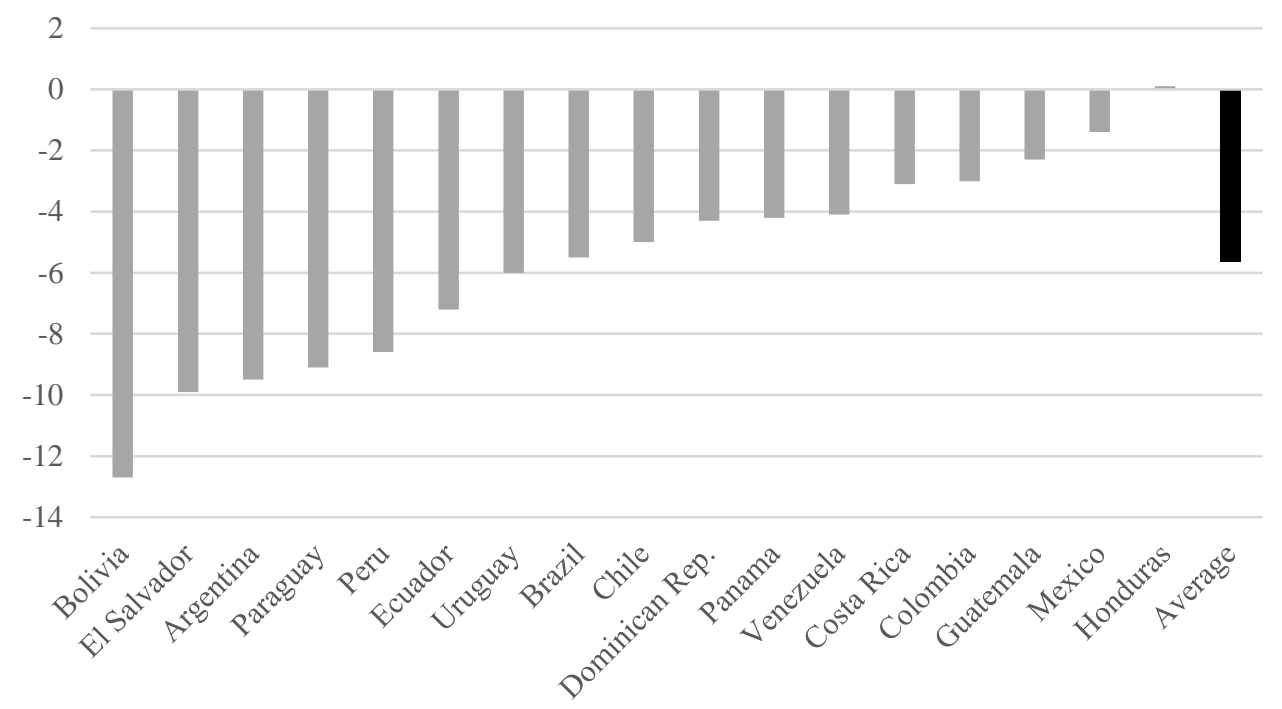

Source: SEDLAC, May 2018.

Some analyses of this trend, however, temper excessive optimism. This decline came after a prolonged rise in inequality and in many cases simply brought inequality back to the level of the early $1980 \mathrm{~s}^{29}$ Since roughly 2011 this inequality decline has slowed or reversed, roughly coinciding with a decline in commodity prices, and many fear that this episode of inequality moderation has already run its course.

A second note of caution relates to the measurement error inherent in surveybased gini estimates. Research from Brazil, drawing on top income shares derived from tax data, shows no clear inequality decline. ${ }^{30}$ This analysis suggests that there was a small decline in the income share of the 'traditional middle class' (the $50^{\text {th }}-90^{\text {th }}$ percentiles), while the top $10 \%$ share increased marginally, raising questions about the appropriate measures and data.

However, while dynamics at the very top of the distribution may be contested, there is strong evidence of above-average income growth in the bottom income deciles in most countries in Latin America, a pattern that contrasts with trends in North America. Several academic studies have used econometric techniques to decompose this distributional change and distinguish the economic drivers of change from policy-driven factors. These studies have attributed Latin America's inequality declines to factors such as a rising educational attainment and falling skills premiums; rising minimum

\footnotetext{
${ }^{2}$ Or closest year available.
} 
wages and increased job formality; devalued exchange rates and better prices for agricultural produce (which helped to reduce the urban-rural gap); better tax collection; an increase in social transfers, including the introduction of non-contributory pension systems in some countries; demographic change resulting in a falling dependency ratio in poor households; and the out-migration of low skilled workers. ${ }^{31}$

Lustig and López-Calva, based on evidence from Argentina, Brazil, Mexico and Peru, argue that a decrease in the skills premium (gap between high and low skilled earnings), and an increase in social transfers, explain most of the decline. ${ }^{32}$. The declining skills premium was a consequence of rising educational supply combined with strong demand for low-skilled workers. A similar exercise by Azevedo et al. corroborated these results, concluding that strong labour income growth among lowincome earners accounted for most of the inequality decline, although an increase in transfers and pensions were also an important driver in many countries. ${ }^{33}$ These shifts were underpinned by a favourable macroeconomic climate. Latin America's terms of trade improved over the 2000s, the export to GDP ratio rose on average, owing to strong demand from Asia. ${ }^{34}$ This helped to boost GDP growth, which increased demand for labour and improved government finances.

But politics also mattered. The decline in inequality coincided with a swing to the left in many parts of the continent. In total, Latin American countries elected 15 different leftist governments between 1998 and 2011. These social democratic leftist governments in Argentina, Brazil, Chile, the Dominican Republic, Ecuador, El Salvador, Panama, Paraguay, Uruguay, and more radical or populist leftist parties in Bolivia, Venezuela and Nicaragua, registered, on average, higher inequality declines than those of centrist or centre-right governments. ${ }^{35}$ But inequality decline was not limited to countries and periods with leftist governments and inequality also declined under some centre-right governments (for instance Mexico and Paraguay).

Roberts has argued that this political shift must be seen in light of sharply rising inequality in the 1980s and 1990s. ${ }^{36}$ Because of the structural adjustment reforms of the 1980s-90s era, which dismantled the existing safety nets for formal sector workers and reduced state employment, in combination with sluggish economic growth and macroeconomic instability, inequality in an already highly unequal Latin America rose to new heights. This crisis era led to greater calls for redistribution, not only among traditional working class, but also among many voters who hadn't historically identified 
with the left. Voters elected new left-leaning governments because of the poor economic record of previous right-wing governments. Furthermore, the political party in power during the structural adjustment phase coloured this process. Where leftist parties formed the opposition during the neoliberal era, they were able to use their networks and support bases to launch a successful political challenge in the 2000s (e.g. Brazil). Where, in contrast, leftist parties had been in power during the 1980s-90s and were complicit in the introduction of neoliberal reforms, they lost credibility. Many of these countries saw the rise of new populist parties that drew their support from outside the traditional party structures (e.g. Bolivia, Venezuela). In these countries, the unemployed, indigenous organisations and other social movements gained ground, in contrast to traditional union-based social movements.

Democratization in the 1980s and 1990s also forms part of the backdrop to this inequality decline. Huber and Stephens attribute Latin America's more redistributive social policies in the 2000s to a democratic coming of age, which enabled this election of left-leaning governments and forced conservative parties to take the concerns of the left seriously. ${ }^{37}$ Robinson has argued that it was those parties with support among the rural poor (for instance in Bolivia, Mexico, Brazil), that introduced the most progressive transfer systems. ${ }^{38}$ Balcázar has used econometric methods to show that cohorts that grew up under democratic regimes in Latin America exhibit lower inequality than others. ${ }^{39}$ He speculates that this effect is driven by a higher supply of public education under democratic conditions.

However, there are already concerns that this inequality moderation has run its course and petered out, as commodity prices fell and economic conditions worsened for many countries after 2011. An emerging literature explores why these inequality declines have slowed or reversed. Morgan argues that in the case of Brazil the increased income share at the bottom of the distribution came at the expense of the middle classes, who gained less from the pro-poor policies of the 2000s. He suggests that this squeezed middle may explain the eventual reduction in support for Brazil's workers party, Partido dos Trabalhadores (PT). Loureiro and Saad-Filho similarly argue that Brazil's inequality declines were achieved through pragmatic and non-confrontational reforms, which made few structural changes to the Brazilian economy and left income shares at the top intact. ${ }^{40}$ When growth slowed and public finances came under pressure, the PT's support base therefore weakened. 
Nonetheless, Latin America's redistributory reforms of the 2000s suggest that even in some of the most unequal countries in the world, popular grievances can, under some conditions, find expression and be constructively met through the ballot box. There may be political limits to inequality escalation, which when breached, tend to trigger a sufficiently strong political backlash to force some political change. ${ }^{41}$ Despite important country differences, the broader commonalities across Latin America during this period also points to the importance of drivers beyond the nation-state, albeit conditioned by the local context.

\section{Asia}

Asian inequality trends in the past three decades have varied across the region, although the largest of the Asian countries (China, India and Indonesia) have seen a decisive rise in inequality since the 1980s, starting from a low base. Many have invoked Kuznetsstyle explanations to account for this rapid rise in inequality coinciding with economic growth and industrialization. ${ }^{42}$ Sharma et al. identify the transition from agriculture to industry and services as an important driver, in combination from the rapid growth in demand for skilled workers which drove up the skills premium. ${ }^{43}$

China and India have perhaps received the greatest attention in the Asian inequality literature. Lakner argues that the Chinese case follows a similar trend to that of Eastern Europe, where the transition to a market economy and structural transformation led to rapidly rising inequality. The rapid growth of the private sector and increase in privately-owned housing and other assets, drove up wage and wealth inequalities. ${ }^{44}$ India deregulated its economy in the 1980s and 1990s and privatized previously state-owned enterprises, which contributed to extreme income growth at the very top of the distribution. ${ }^{45}$ However, possibly signalling that China's inequality has already peaked, the data suggests a downturn in inequality around 2006-08, possibly due to the diminishing availability of unskilled rural labour. ${ }^{46}$

But the Chinese and Indian trends may not be generalisable for the continent at large. For many Asian countries the inequality data is sparse and of mixed quality, and for two countries there is reasonably robust evidence of declining inequality over the same period: Thailand and Malaysia.

Thailand and Malaysia are outliers in inequality terms, as in the early postwar era both had unusually high inequality, relative to their neighbours. Thailand's gini rose 
from roughly 0.41 in 1962 to 0.54 in 1992, a level of inequality rivalling that of Latin America, and exceptionally high by Asian standards. ${ }^{47}$ Inequality fell after 1992, particularly after the 1997 Asian crisis, bringing the gini down to 0.46 by $2013,{ }^{48}$ although, as in Brazil, the more fragmentary evidence on top income shares suggests that this decline in the gini may not be mirrored by a corresponding decline in the top percentile share. $^{49}$

Economic forces explain much of this fall. The 1997 Asian crisis hit the urban areas disproportionately, and the devaluation of the Baht helped rural exporters, while constraints to labour began to push up unskilled wages. ${ }^{50}$ But this inequality reversal also coincided with stronger public calls for democratization, and a new 1997 constitution facilitated a return to democracy. Thaksin Shinawatra's rule (2001-06) saw the introduction of some pro-poor measures, including universal healthcare, microfinance schemes, a moratorium on farmer debt and subsidies for rural producers. His rule was cut short by a 2006 coup, and Thailand has continued to oscillate between democratic and military rule since. Many have interpreted this political struggle, between populist politicians and an old, monarchical guard supported by the military, in class terms. ${ }^{51}$ Thaksin drew support from the working classes, galvanized through a series of street protests (by the so-called red shirts), who used a rhetoric of class and inequality to mobilize supporters. ${ }^{52}$

Malaysia's inequality decline is confined to the late 1970s and early 1980s, when, in response to race riots, the government introduced an affirmative action programme designed to benefit ethnic Malays. The 1971 New Economic Policy (NEP), which introduced affirmative action and poverty reduction policies, in an effort to narrow the gaps between the Bumiputera (ethnic Malay) majority and Chinese and Indian minorities. ${ }^{53}$ It provides an interesting case where political imperatives to tackle horizontal inequalities (between social groups) may also have helped to reduce vertical ones (between individuals).

The NEP combined more traditional developmental programmes such as rural development and education, with active affirmative action aiming to reduce foreignand minority ownership of capital. It used quota systems and preferential access to credit and pricing to increase the economic empowerment of ethnic Malays. It also increased Malay representation in higher education and gave the group preference in public employment. ${ }^{54}$ Several studies have concluded that inequality declined sharply 
during the second phase of the NEP, falling from 0.53 in 1976 to 0.45 in $1990,{ }^{55}$ although the decline in the top percentile income share was more modest. ${ }^{56}$ These two country cases highlight the variation in the inequality trajectories across the Asian continent, and as in the Latin American case, point to the role of popular pressures in forcing policy change and redistribution.

\section{Middle East and North Africa}

While the data is scarce and patchy, income inequality in the MENA region is thought to be relatively low in relation to the regions income per capita. A recent study by Hassine harmonized microdata from household surveys for 12 countries in the Arab region. ${ }^{57}$ She finds no generalizable trend across the region, with increases in Syria, Yemen, Djibouti and Palestine, and decreases in Egypt, Jordan and Tunisia.

Recent literature on inequality in the MENA region has sought to relate it to the Arab Spring. Many papers revolve around the 'Arab inequality puzzle': despite moderate inequality by global standards and no obvious rise in inequality, the region saw considerable social upheaval in 2010-11 in what was widely perceived to be inequality-related grievances. ${ }^{58}$

Some have argued the squeezed middle class, rather than inequality per se, explains growing dissatisfaction in the region. Perception surveys reveal considerably lower self-reported life satisfaction than in other countries at roughly the same level of income per capita. ${ }^{59}$ These surveys also suggest that dissatisfaction was more pronounced among the top $60 \%$ than the bottom $40 \%$. Hassine suggests that the breakdown of the social protection system as well as reduced state employment opportunities for the middle and upper middle classes during the structural reforms of the 1990 s may explain this dissatisfaction. ${ }^{60}$ In the pre-adjustment era, inequality was managed both through migration and state employment, which was used to balance incomes geographically and ensure continued returns to skills. Counter-intuitively, a squeezed middle class may result in falling inequality, if income growth is comparatively faster at the bottom of the distribution than the upper middle.

This dynamic may explain the trends in Tunisia and Algeria. Although estimates differ somewhat across studies, several find a flat or modestly declining gini from the late 1990s until c.2010, despite being at the epicentre at the Arab Spring. Both countries succeeded in retaining comparatively high levels of social spending during a period of 
liberalisation from the late 1980s and onward, in contrast to other countries in the region. ${ }^{61}$ An important change during this era of structural reform however, was the reduction of job opportunities in the government and parastatal sectors. ${ }^{62}$ But as these public sector jobs disproportionately benefitted the upper half of the income distribution, this reform was not necessarily inequality increasing - it may in fact have lowered the distance between the poorer segments of society and the middle and upper middle.

Another, somewhat anomalous country case is Iran, where the 1979 revolution brought to power a left-leaning theocracy led by the Ayatollah Khomeini. Through an analysis of a broad set of inequality and poverty data, Salehi-Isfahani has posed the question of whether the Iranian revolution, which defined itself as a movement of the "disinherited" and "barefooted", did in fact reduce poverty and inequality. ${ }^{63} \mathrm{He}$ concludes that inequality and poverty dropped sharply in the immediate aftermath of the revolution, owing to confiscation of wealth, nationalisation of industry and emigration of Iran's elites. Inequality fell further towards the end of the Iran-Iraq War (1980-88), as oil rents dwindled, but poverty rose. From the late 1980s, inequality remained steady for almost 30 years and policies included substantial income redistribution.

In 2010 inequality dropped further, in tandem with the introduction of the Targeted Subsidies Program. ${ }^{64}$ This programme sought to phase out Iran's substantial, and regressive, fuel subsidies (estimated at $20 \%$ of GDP), and replace them with an unconditional transfer. Using the 2011/12 household expenditure and income survey, researchers have found that this transfer reduced final, net inequality by 4 gini pts relative to market income inequality ${ }^{65}$ although the longevity of this improvement in income distribution remains in question, as inflation increased and the real value of the transfer decreased.

These three cases point to a different type of country trajectory, where leadership by repressive, authoritarian regimes, characterized by considerable state intervention in the economy and active government-led redistribution, may have allowed greater autonomy from global policy norms - although political upheavals throughout the region may signal that these states' abilities to balance popular interests has waned. 


\section{Sub-Saharan Africa}

With the exception of South Africa, the literature on inequality dynamics on in subSaharan Africa is thin. Few papers have exploited the data in the global databases due to data quality concerns. Even level differences between countries show large variations, which point to possible data quality and comparability issues. Most studies of inequality trends therefore limit their analysis to counting the number of countries with inequality falls versus declines. The World Bank's data suggests that the average gini has declined in the past two decades, with inequality falling in more countries than it was increasing between 1993 and 2013. ${ }^{66}$ A study using an asset-based gini instead, derived from Demographic and Health Surveys (DHS), finds no clear trend in asset inequality between 1995 and 2013. ${ }^{67}$

The stylized political and economic trajectory since the 1990s gives mixed inequality predictions. Many countries re-introduced multiparty elections in the 1990s, while the intensity of conflict has declined and growth has rebounded, which suggests greater policy space and political incentive to tackle distributive issues. But in many countries this growth rebound owed much to the extractive industries, which many predict would lead to increased income inequality. ${ }^{68}$

Urban-rural inequalities have long been a source of debate in the Africanist literature, with scholars in the 1970s and 1980s concluding that the urban-bias was a key social cleavage in Africa. Many studies therefore used urban-rural income differentials as their main measure of social inequality. Consequently, some expected the structural reforms of the 1990s to be inequality reducing, as they sought to raise the rural-urban terms of trade and offered small-holders higher prices for their cash crops. ${ }^{69}$ Evidence of recent changes in urban-rural inequality is limited. A study using asset indices and health and education measures from the DHS, found no strong signs of either convergence or divergence, with a mixed track record across the 24 countries in their sample. ${ }^{70}$

Shifting urban-rural terms of trade may, however, explain the more recent downward trend in inequality in a cluster of countries in West Africa - Burkina Faso, Guinea, Mali, Mauritania and Niger - according to the available data from PovcalNet (Figure 3). In most cases the inequality decline started in the mid-late 1990s, but the strongest gini drops are in the second half of the 2000s, starting around 2005. These 
inequality declines coincide with a recovery in growth and an improvement in the terms of trade.

While the literature on inequality in this region is relatively limited, it suggests that crop prices explain most of this fall. The increase in food prices and some cash crops during the 2000s benefitted poor, rural food producers and hurt comparatively wealthier urban dwellers. There is also some suggestion that the higher food prices increased rural agricultural wages. Consequently, the rural-urban income gap narrowed and the income distribution compressed. Figure 4 plots the FAO food price index. Prices began to rise in the early 2000s, spiked in 2008 and 2011, but have remained considerably higher than in the 1990s. These drivers of change were thus largely exogenous to domestic policymaking, although the fact that governments did not intervene forcefully to hold down producer prices is noteworthy, ${ }^{71}$ and may reflect growing rural bargaining power. Bates and Block, for instance, argue that increased electoral competition in Africa since the late 1990s has led to greater government responsiveness to rural interests, including through more favourable pricing of agricultural produce. ${ }^{72}$

\section{Figure 3. Gini indices for five countries in West Africa}

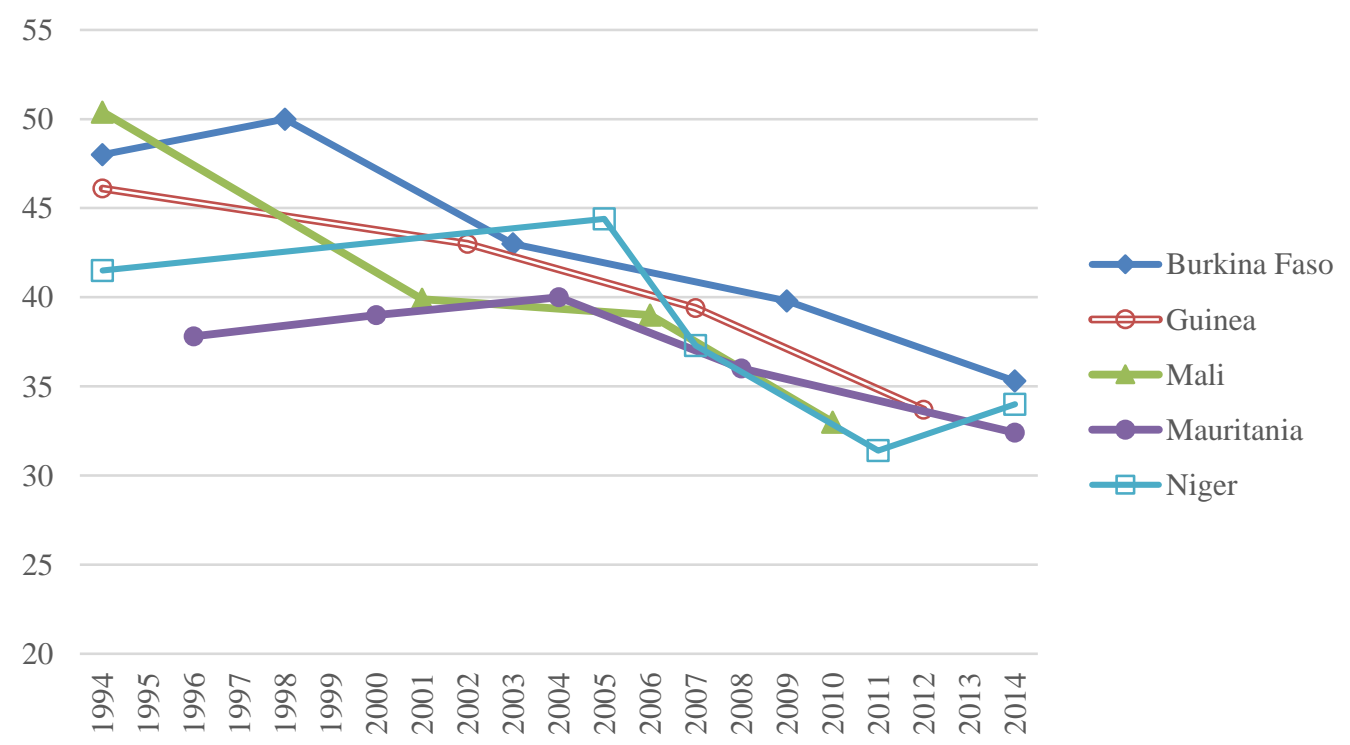

Source: PovcalNet, 2019. 


\section{Figure 4. FAO food price index (deflated) 1990-2017}

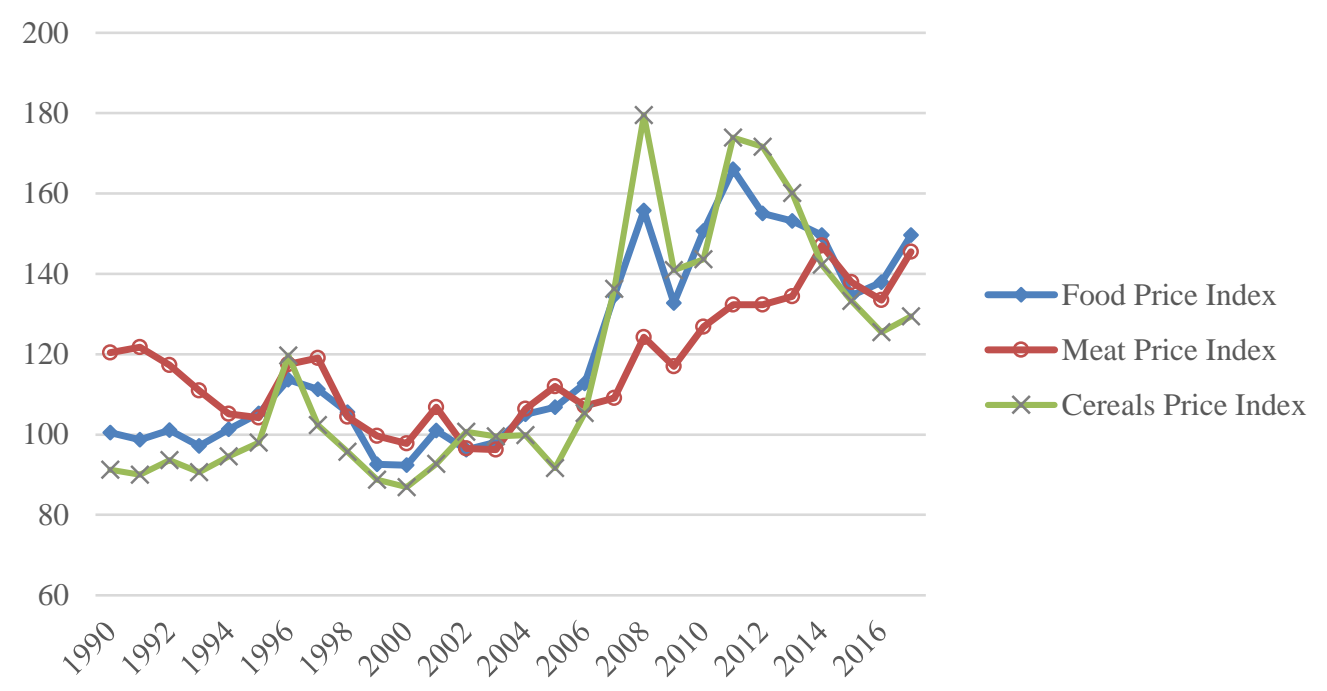

Source: FAO 2017.

\section{Conclusion}

In this paper we have brought the experience of nations which have seen inequality decline in recent decades to the fore, in an effort to rebalance attention towards inequality trends across developing countries, rather than examining the globe as a single unit. This paper has reviewed the existing sources of inequality data and used the best current estimates to identify recent inequality trends. While it is possible that this picture will change if and when more data on top income shares becomes available, the current state of knowledge suggests that there are significant parts of the world where inequality has declined over the past two decades. We argue that these nations offer important lessons for reflecting on theoretical debates about inequality and illustrate that we should not assume that there are global secular and generic trends towards escalating inequalities.

A first point to note is that most of our case study countries had comparatively high levels of income inequality prior to the inequality decline. Latin America is frequently deemed to have the highest levels of inequality in the world, while Thailand, Malaysia and pre-revolution Iran had high inequality relative to their regional peers. Many of these countries also had limited involvement in the First and Second World 
Wars, which may help to explain their high inequality in the post-war era. ${ }^{3}$ These cases indicate that there might be political limits to inequality escalation. When inequality in Latin America rose to new heights in the 1990s, it appears to have triggered a sufficiently strong political backlash to reverse some of the most egregious social costs of neoliberal reforms. The same might be said for Thailand and Malaysia, and possibly pre-revolution Iran. It is therefore possible to read these cases as examples of the 'Kuznets waves' proposed by Milanovic; the eventual restraining forces that are unleashed once countries reach a particularly high inequality frontier. ${ }^{73}$ In accordance with Milanovic, these 'benign' restraints on inequality appear to be a consequence of economic change and political pressures, i.e. endogenous to rising inequality.

Furthermore, the patterns we observe in this study suggests that external economic forces have played a considerable role in inequality decline. Although there is clearly important country variation, the regional commonalities in Latin America and West Africa for instance, suggests that cross-national drivers are having similar effects across countries with similar initial conditions. For instance, existing decomposition studies point to the importance of factors such as rising agricultural prices, which increased rural labour demand, as particularly relevant in the African cases. Changing skills premia, driven by educational expansion and changing sectors of growth, are thought to have been particularly important in Latin America and Asia, in line with Tinbergen's theory. Furthermore, improved terms of trade, macroeconomic stability and healthier state finances allowed the expansion of social safety nets in Latin America.

Possibly because inequality had reached new heights in the 1990s, there was also an active and successful political discourse around redistribution and policy reforms that explicitly sought to ameliorate or reverse some of the inequality gains in the preceding decades. In Latin America, Tunisia, Iran, Thailand and Malaysia for instance, new political movements used a discourse of inequality to galvanize support for reform and politicians justified their actions on inequality reduction grounds. While the African dynamics remain understudied, recent scholarship has pointed to the importance of democratisation in limiting the extent to which governments could

\footnotetext{
${ }^{3}$ If we subscribe to the arguments by Piketty, Scheidel and others, that the world wars were the catalysts for inequality decline.
} 
suppress rural producer prices for commodities - arguably one of the main drivers of rural-urban inequality in the early independence era. ${ }^{74}$

Yet we also need to recognise that among most of the countries highlighted in this study, policy reforms were largely within the confines of an internationallysanctioned economic framework. Most countries continued to pursue macroeconomic stability, few sought to increase state involvement in productive sectors, and most of the reforms and investments in education and basic social safety nets had the blessing of the World Bank and other international organisations. ${ }^{75}$ An important question is therefore whether these modest reforms have already run their course and whether we will now see a swing back towards stable or higher levels of inequality. Furthermore, without recourse to other inequality data sources, it is difficult to tell if declining gini indices are mirrored by corresponding falls in top income shares, or whether the compression was largely between bottom and middle.

It may also be too soon to reject the idea that institutional path dependence has set countries at different inequality levels, in ways that make structural inequalities hard to break. ${ }^{76}$ Despite a noteworthy convergence in inequality levels across regions of the world, regional and country rankings have remained largely intact.

Yet these varied inequality trajectories offer some hope that inequality can be moderated, if not radically altered, through comparatively peaceful means, without the need for revolution, war or natural catastrophes. They point to some of the ways in which popular demands have at times been met through democratic channels, such as through increased education provision, income and pricing policies and social transfers. Furthering such efforts to counter inequality are crucial for the sustainability of $21 \mathrm{st}$ century societies across the world, and thus deserve sustained research and policy attention. 


\title{
Datasets
}

\author{
FAO FAO food price index, \\ http://www.fao.org/fileadmin/templates/worldfood/Reports_and_docs/Food_price in \\ dices data.xls [Accessed Jan 2018]. \\ GCIP Lahoti, Rahul, Jayadev, Arjun and Reddy, Sanjay G., 2016, “The Global \\ Consumption and Income Project (GCIP): An Overview.” http://gcip.info/ \\ POVCALNET World Bank, Povcalnet, http://iresearch.worldbank.org/PovcalNet/home.aspx \\ [accessed: June 2019] \\ SEDLAC CEDLAS and The World Bank, May 2018, Socio-Economic Database for Latin \\ America and the Caribbean, \\ http://www.cedlas.econo.unlp.edu.ar/wp/en/estadisticas/sedlac/estadisticas
}

\section{Bibliography}

Acemoglu, Daron, Simon Johnson, and James A. Robinson. "The colonial origins of comparative development: An empirical investigation." American Economic Review 91, no.5 (2001): 1369-1401.

Albrecht, Scott, and Roberto Patricio Korzeniewicz. "Systems Perspective Billionaires and the Great Recession of 2008." in Global Inequalities in World-Systems Perspective: Theoretical Debates and Methodological Innovations, edited by Manuela Boatca, Andrea Komlosy, Hans-Heinrich Nolte, New York: Routledge, 2017.

Alvaredo, Facundo., Chancel, Lucas., Piketty, Thomas, Saez, Emmanuel. \& Zucman, Gabriel. World Inequality Report 2018, World Inequality Lab, 2017.

Alvaredo, Facundo, and Leonardo Gasparini. "Recent Trends in Inequality and Poverty in Developing Countries." In Handbook of Income Distribution, Volume 2A, edited by A. B. Atkinson and F. Bourguignon. Elsevier B.V., 2015.

Anand, Sudhir, and Paul Segal. "Who are the global top 1\%?." World Development 95 (2017): 111-126.

Atkinson, Anthony. B., and A. Brandolini. "On Data: A Case Study of the Evolution of Income Inequality across Time and across Countries.” Cambridge Journal of Economics 33, no. 3 (2009): 381-404.

Atkinson, Anthony B. Inequality: What Can Be Done? Cambridge and London: Harvard University Press, 2015.

—_. "Top Incomes in Malaysia 1947 to the Present.” WID.world Technical Note., 2015.

Azevedo, Joao Pedro, Gabriela Inchaust, and Viviane Sanfelice. "Decomposing the Recent Inequality Decline in Latin America.” Policy Research Working Paper 6715, Washington D.C.: World Bank, 2013.

Balcázar, Carlos Felipe. "Long-Run Effects of Democracy on Income Inequality in Latin America." Journal of Economic Inequality 14, no.3 (2016): 289-307.

Bates, Robert H., and Steven A. Block. "Revisiting African agriculture: institutional change and productivity growth." The Journal of Politics 75, no. 2 (2013): 372-384.

Beegle, Kathleen, Luc Christiaensen, Andrew Dabalen, and Isis Gaddis. Poverty in a rising Africa. Washington D.C.: World Bank, 2016.

Birdsall, Nancy, Nora Lustig, and Darryl McLeod. "Declining inequality in Latin America: some economics, some politics", Centre for Global Development Working Paper 251, 2011.

Bourguignon, François, and Christian Morrisson. "Inequality among world citizens: 18201992." American Economic Review 92, no. 4 (2002): 727-744.

Corak, Miles. "Income inequality, equality of opportunity, and intergenerational mobility." Journal of Economic Perspectives 27, no. 3 (2013): 79-102. 
Cornia, Giovanni Andrea. Falling Inequality in Latin America : Policy Changes and Lessons. World Institute for Development Economics Research, 2014.

El-Said, Hamed, and Jane Harrigan. "Economic Reform, Social Welfare and Political Instability in the Arab World: The Case of Jordan, Egypt, Morocco, and Tunisia 1983-2004.” Middle East Journal 68, no. 1 (2014): 99-121.

Enami, Ali, Nora Lustig, and Alireza Taqdiri. The Role of Fiscal Policy in Fighting Poverty and Reducing Inequality in Iran: An Application of the Commitment to Equity (CEQ) Framework. Giza, 2016.

Engerman, Stanley L., and Kenneth L. Sokoloff. "Factor endowments, institutions, and differential paths of growth among new world economies." In How Latin America Fell Behind, edited by Stephen Haber, California: Stanford University Press, 1997: 260-304.

Galbraith, James K. "Global inequality and global macroeconomics." Journal of Policy modeling 29, no. 4 (2007): 587-607.

Goldin, Claudia, and Lawrence F. Katz. The race between education and technology, Harvard University Press, 2008.

Grugel, Jean, and Pía Riggirozzi. "Post-neoliberalism in Latin America: Rebuilding and reclaiming the State after crisis." Development and change 43, no. 1 (2012): 1-21.

Handoussa, Heba, and Zafiris Tzannatos. Employment Creation and Social Protection in the Middle East and North Africa. Cairo and New York: World Bank / American University in Cairo Press, 2002.

Hassine, Nadia Belhaj. "Economic Inequality in the Arab Region.” World Development 66 (2015): 53256.

Hewison, Kevin. "Considerations on Inequality and Politics in Thailand." Democratization 21, no. 5 (2014): 846-66.

Huber, Evelyne, and John D. Stephens. Democracy and the Left: Social Policy and Inequality in Latin America. University of Chicago Press, 2012.

Ianchovichina, Elena, Lili Mottaghi, and Shantayanan Devarajan. Inequality, Uprisings, and Conflict in the Arab World. MENA Economic Monitor. Washington D.C.: World Bank, 2015.

Ikemoto, Yukio, and Mine Uehara. "Income Inequality and Kuznets' Hypothesis in Thailand.” Asian Economic Journal 14, no. 4 (2000): 421-43.

Jenkins, Stephen P. "World Income Inequality Databases: An Assessment of WIID and SWIID.” Journal of Economic Inequality 13, no. 4 (2015): 629-71.

Jones, William J. "Pasuk Phongpaichit and Chris Baker (Eds.), Unequal Thailand: Aspects of Income, Wealth and Power." Journal of Contemporary Asia 47, no. 4 (2017): 668-71.

Korzeniewicz, Roberto Patricio, and Timothy Patrick Moran. Unveiling inequality: a world-historical perspective. Russell Sage Foundation, 2009.

Krongkaew, Medhi, and Haji Mat Zin Ragayah. Income Distribution and Sustainable Economic Development in East Asia: A Comparative Analysis. Paper presented at the Conference on "Economic Openness and Income Inequality: Policy Options for Developing Countries in the New Millennium", 2006.

Kuznets, Simon. "Economic growth and income inequality." The American economic review 45, no. 1 (1955): 1-28.

Lakner, Christoph. "Global Inequality." In After Piketty: The Agenda for Economics and Inequality, eds. Heather Boushey, J. Bradford DeLong, and Marshall Steinbaum. Harvard University Press, 2017.

Lee, Hwok-Aun. "Racial Inequality and Affirmative Action in Malaysia and South Africa." PhD Thesis, Department of Economics, University of Massachusetts, 2010.

Li, Shi, and Terry Sicular. "The Distribution of Household Income in China: Inequality, Poverty and Policies.” The China Quarterly 217 (2014): 1-41. 
López-Calva, Luis F., and Nora Lustig. "Explaining the Decline in Inequality in Latin America: Technological Change, Educational Upgrading, and Democracy.” In Declining inequality in Latin America: A decade of progress?, edited by Luis Felipe López-Calva and Nora Claudia Lustig, Brookings Institution Press, 2010.

Loureiro, Pedro Mendes, and Alfredo Saad-Filho. "The Limits of Pragmatism: The Rise and Fall of the Brazilian Workers' Party (2002-2016).” Latin American Perspectives (2018).

Milanovic, Branko. Global Inequality: A New Approach for the Age of Globalization. Cambridge, Massachusetts: Harvard University Press, 2016.

Moynihan, Colin “In 'Occupy,' Well-Educated Professionals Far Outnumbered Jobless, Study Finds” The New York Times (Jan 28, 2013), available at: https://cityroom.blogs.nytimes.com/2013/01/28/inoccupy-well-educated-professionals-far-outnumbered-jobless-study-finds/ (last viewed 3/2019).

Morgan, Marc. Extreme and Persistent Inequality: New Evidence for Brazil Combining National Accounts, Surveys and Fiscal Data, 2001-2015. WID.world Working Paper, 2017.

Onuoha, Godwin. "A 'rising Africa' in a resource-rich context: Change, continuity and implications for development." Current Sociology 64.2 (2016): 277-292.

Phongpaichit, Pasuk. "Inequality, Wealth and Thailand's Politics." Journal of Contemporary Asia 46, no. 3 (2016): 405-24.

Piketty, T., L. Yang, and G. Zucman. Capital Accumulation, Private Property and Rising Inequality in China, 1978-2015. WID.world Working Paper, 2016.

Piketty, Thomas. Capital in the Twenty-First Century. Cambridge, Mass.: Belknap Press, 2014.

Piketty, Thomas, and Emmanuel Saez. "Income inequality in the United States, 1913-1998." The Quarterly journal of economics 118, no. 1 (2003): 1-41.

Putnam, Robert D. Our kids: The American dream in crisis. New York: Simon and Schuster, 2016.

Roberts, Kenneth M. “The Politics of Inequality and Redistribution in Latin America's Post-Adjustment Era." In Falling Inequality in Latin America: Policy Changes and Lessons, edited by Giovanni Andrea Cornia. Oxford University Press, 2014.

Robinson, James A. "The Political Economy of Redistributive Policies." In Declining Inequality in Latin America: A Decade of Progress?, edited by Luis Felipe López-Calva and Nora Claudia Lustig, Brookings Institution Press, 2010.

Sahn, D. E., and David C. Stifel. "Urban-Rural Inequality in Living Standards in Africa." Journal of African Economics 12, no. 4 (2003): 564-97.

Sahn, David, Paul Dorosh, and Stephen Younger. Structural Adjustment Reconsidered : Economic Policy and Poverty in Africa. Cambridge and New York: Cambridge University Press, 1997.

Salehi-Isfahani, Djavad. "Poverty, Inequality, and Populist Politics in Iran." The Journal of Economic Inequality 7, no. 1 (2009): 5-28.

Scheidel, Walter. The Great Leveler: Violence and the History of Inequality from the Stone Age to the Twenty-First Century. Princeton, New Jersey: Princeton University Press, 2017.

Shari, Ishak. "Economic Growth and Income Inequality in Malaysia, 1971-95." Journal of the Asia Pacific Economy 5, no. 1-2 (2000): 112-24.

Sharma, Manohar, Gabriela Ichauste, and Juan Feng. An Eye on East Asia and Pacific: Rising Inequality with High Growth and Falling Poverty. Washington D.C.: World Bank, 2011.

Shimeles, Abebe, and Tiguene Nabassaga. 2017. Why Is Inequality High in Africa? African Development Bank Group Working Paper Series no.246.

Statistical Centre of Iran. 2014. 1392 Summary Results of the Iranian Urban and Rural Household Income and Expenditure Survey - Year 1392.

Tinbergen, Jan. "Substitution of graduate by other labour." Kyklos 27, no. 2 (1974): 217-226.

Bashi Treitler, Vilna, and Manuela Boatcă. "Dynamics of inequalities in a global perspective: An 
introduction." Current Sociology Monograph, 64, no.2 (2016): 159-171.

Wilkinson, Richard, and Kate Pickett. The spirit level: Why equality is better for everyone. London, Penguin UK, 2010.

World Bank. Getting Back on Track: Reviving Growth and Securing Prosperity for All: Thailand Systematic Country Diagnostic. Washington D.C.: World Bank, 2016.

. Taking on Inequality: Poverty and Shared Prosperity 2016. Washington D.C.: World Bank, 2016.

\section{Notes}

${ }^{1}$ Piketty, Capital; Scheidel, Great Leveler.

${ }^{2}$ Corak, Income Inequality, Wilkinson and Pickett, Spirit Level; Putnam, Our Kids.

${ }^{3}$ Anand and Segal, "Global Top", discuss the threshold of the global 1\%. In fact, even in American terms, it appears that substantial numbers of protesters were not in the $99 \%$. See: Moynihan, "Occupy".

${ }^{4}$ Milanovic, Global Inequality, 122; Anand and Segal, "Global Top".

${ }^{5}$ Birdsall, Lustig and McLeod, "Declining inequality"; López-Calva et al., "Explaining the decline"; Cornia, "Falling inequality".

${ }^{6}$ Beegle et al., Poverty; Hassine, "Economic Inequality".

${ }^{7}$ Piketty and Saez, "Income Inequality".

${ }^{8}$ Wilkinson and Pickett, Spirit Level.

${ }^{9}$ Bourguignon and Morrisson, "Inequality"; Galbraith, "Global Inequality"; Milanovic, "Global Inequality"; Korzeniewicz and Moran, Unveiling Inequality; Anand and Segal, "Global Top"; Alvaredo et al., World Inequality Report.

${ }^{10}$ Bourguignon and Morrisson, "Inequality"

${ }^{11}$ Korzeniewicz and Moran, Unveiling Inequality; Treitler and Boatcă, "Dynamics".

${ }^{12}$ Milanovic, Global Inequality, 128-133; see also Anand and Segal, "Global Top".

${ }^{13}$ Alvaredo et al., World Inequality Report.

${ }^{14}$ For instance: Korzeniewicz and Albrecht, Systems perspective.

${ }^{15}$ Milanovic, Global Inequality; Alvaredo et al., World Inequality Report.

${ }^{16}$ Kuznets, "Economic Growth".

${ }^{17}$ Tinbergen, "Substitution"; Goldin and Katz, Race.

${ }^{18}$ Atkinson, Inequality.

${ }^{19}$ Piketty, Capital; Scheidel Great Leveler.

${ }^{20}$ Milanovic, Global Inequality.

${ }^{21}$ Engermann and Sokoloff, "Factor Endowments"; Acemoglu, Johnson and Robinson, "Colonial Origins"; Korzeniewicz and Moran, Unveiling Inequality.

${ }^{22}$ Alvaredo et al., World Inequality Report.

${ }^{23}$ Atkinson and Brandolini, "On Data"; Jenkins "World Income".

${ }^{24}$ Alvaredo and Gasparini, "Recent Trends"; Lakner, "Global Inequality"; World Bank, Taking On.

${ }^{25}$ This convergences has been noted and formally tested by others, see for instance: Alvaredo and Gasparini, "Recent Trends".

${ }^{26}$ Alvaredo and Gasparini, "Recent Trends"; Lakner, "Global Inequality".

${ }^{27}$ Alvaredo and Gasparini, "Recent Trends".

${ }^{28}$ Cornia, Falling Inequality.

${ }^{29}$ Lakner, "Global Inequality"; Scheidel, Great Leveler.

${ }^{30}$ Morgan, "Extreme and Persistent".

${ }^{31}$ Cornia, Falling Inequality; Lustig and López-Calva "Explaining."; Azevedo et al., "Decomposing". 
${ }^{32}$ López-Calva and Lustig, "Explaining."

${ }^{33}$ Azevedo et al., "Decomposing".

${ }^{34}$ Cornia, Falling Inequality.

${ }^{35}$ Cornia, Falling Inequality, 15; This builds on Cornia and Roberts classification of regime types. For an alternative classification, see: Birdsall, Lustig and McLeod, "Declining inequality",

${ }^{36}$ Roberts, "Politics".

${ }^{37}$ Huber and Stephens, Democracy.

${ }^{38}$ Robinson, "Political Economy".

${ }^{39}$ (Balcázar, "Long-run Effects".

${ }^{40}$ Loureiro and Saad-Filho, "Limits of Pragmatism".

${ }^{41}$ E.g.: Milanovic, Global Inequality.

${ }^{42}$ Krongkaew and Ragayah, "Income Distribution".

${ }^{43}$ Sharma et al., "An Eye".

${ }^{44}$ Lakner "Global Inequality"; Alvaredo et al., World Inequality Report, 107

${ }^{45}$ Alvaredo et al., World Inequality Report, 123-130.

${ }^{46} \mathrm{Li}$ and Sicular, "Distribution"; Piketty, Yang and Zucman, "Capital Accumulation".

${ }^{47}$ Phongpaichit, "Inequality".

${ }^{48}$ World Bank, Back on Track.

${ }^{49}$ Phongpaichit, "Inequality".

${ }^{50}$ World Bank, Back on Track; Ikemoto and Uehara, "Income Inequality".

${ }^{51}$ Phongpaichit, "Inequality"; Hewison, "Considerations"; Jones, "Unequal Thailand".

${ }^{52}$ Hewison, "Considerations".

${ }^{53}$ Atkinson, Inequality; Krongkaew and Ragayah, "Income Distribution".

${ }^{54}$ Lee, Racial Inequality.

${ }^{55}$ Shari, "Economic Growth".

${ }^{56}$ Atkinson, "Top Incomes".

${ }^{57}$ Hassine, "Economic Inequality".

${ }^{58}$ Ianchovichina, Mottaghi and Devarajan, "Inequality"; Hassine, "Economic Inequality".

${ }^{59}$ Ianchovichina, Mottaghi and Devarajan, "Inequality".

${ }^{60}$ Hassine, "Economic Inequality".

${ }^{61}$ El-Said and Harrigan, "Economic Reform".

${ }^{62}$ Handoussa and Tzannatos, Employment Creation.

${ }^{63}$ Salehi-Isfahani, "Poverty".

${ }^{64}$ Statistical Centre of Iran, Summary Results.

${ }^{65}$ Enami et al., "Role of Fiscal."

${ }^{66}$ World Bank, Taking on Inequality.

${ }^{67}$ Shimeles and Nabassaga, "Why is Inequality High".

${ }^{68}$ Onuoha, "Rising Africa."

${ }^{69}$ Sahn, Dorosh and Younger, Structural Adjustment.

${ }^{70}$ Sahn and Stifel, "Urban-Rural".

${ }^{71}$ World Bank, Taking on Inequality.

${ }^{72}$ Bates and Block, "Revisiting."

${ }^{73}$ Milanovic, Global Inequality.

${ }^{74}$ Bates and Block, "Revisiting."

${ }^{75}$ For a similar argument, see concept of 'post-neoliberalism' as an evolution rather than break with the neoliberalism: Grugel and Riggirozzi, "Post-neoliberalisim", p.6.

${ }^{76}$ E.g. Korzeniewicz and Moran, Unveiling Inequality. 